\title{
The Comparison of Cooperative Learning Models of Number Head Together (NHT), Think Pair Square (TPS), and Student Team Achievement Division (STAD) on Maths at State Junior Secondary Schools (SJSS) in Pekanbaru-Riau Province-Indonesia
}

\author{
Zulkarnain \\ Lecturer of Maths Education Study Program FKIP University of Riau \\ Email: stoper65@yahoo.com
}

\author{
Doi:10.5901/mjss.2016.v7n3p389
}

\begin{abstract}
This research was aimed at finding out the implementation and the effect of cooperative learning models called Student Team Achievement Division (STAD), Think Pair Square (TPS), and Number Head Together (NHT) on the achievement of Class VIII students of State Junior Secondary Schools (SJSS) Pekanbaru in the academic year 2014-2015. This research was quasiexperimental and the design of this research is the design of random pre-test - post-test group comparison. The population was all students of Class VIII SJSS Pekanbaru with a-one-class sample, i.e. SJSS 14, SJSS 21, and SJSS 22 totalling 100 students as the experimental class. The sample was collected by using stratified random sampling. The data was gathered using tests and observation. The used tests was the pre-test and post-test in the form of descriptions and validated by experts. Data were analyzed by using one-way ANOVA test and t-test for paired observational data at $\alpha=0.05$. Data analysis indicated that cooperative learning gave positive effects to the teaching and learning process. The results of the pre-test showed that there was no significant difference between the mean scores of the experimental classes, meaning that the three experimental groups had the same initial ability. On the other hand, the results of the post-test showed that there was also no significant difference between the mean scores of the three experimental groups. It means that there was no significant difference of the three cooperative learning models employed. However, the results of the data analysis of both pre-test and post-test of every group sample showed significant difference where the results of the post-test were better than that of the pre-test. It showed that the given cooperative learning model to the three sample groups gave the better influence than the conventional learning.
\end{abstract}

Keywords: Model, Learning, Cooperative, Maths

\section{Introduction}

The aim of teaching Math at Junior Secondary School among others (1) to train the way of thinking and reasoning in drawing conclusions, (2) to develop creative activities involving imagination, intuition and findings by developing thoughts, the desire to know to make predictions, assumption and trying to do things, (3) to develop the ability to solve problems (Directorate General of Basic Education, 2006).

Maths is one of the sciences that plays a key role in developing knowledge and technology; that is, as a means of shaping thoughts and mathematical attitude, preparing students to have logical thinking, being analytic, systematic, critical and cooperative. Therefore, teachers are expected to be able to design and implement the teaching and learning process appropriately in order that students obtain adequate knowledge so that they consider learning as an enjoyable activity.

The learning process that can guide and train students to be able to solve problems is not yet achieved to this end. Field experience has indicated that there have been weaknesses in the implementation of the teaching and learning Math as it does not prepare students to solve problems. Among other findings are that (1) learning Math is limited to preparing students to be able to deal with the questions in a test (Armanto,2002). All question items are in the form of objective tests where students tend to learn Math by memorizing item samples or learning questions with the answer keys available; (2) Learning Math is kept separate from daily experiences (Zulkarnain, 2005); (3) Teachers lack of learning pedagogy (Zaenab, 2004); (4) Math teachers teach using conventional methods (Zulkardi, 2005).

On the other side, Maths seems to be the subject students have disliked since they were at elementary school and their achievement in this subject is in fact low (Soejadi, 2005). Supartono (2006) claims that many students still have difficulties in learning Math partly because teachers use monotonous teaching techniques from abstract to concrete so that students are not motivated in learning. In addition, Rohani (2005) views that students learn Math without knowing its benefits which means there is a big problem in Math education in the country (Zulkardi, 2007). The problem is that the 
students' ability in solving problems related to daily life is still low and the average result of the annual national exam in Math is lower than other subjects (Provincial Education Office of Riau Province, 2011).

There are many factors that cause the students to be unable to complete the tasks and have low ability in Math, among others the learning factor. The learning that places the students as the individuals who just receive the mathematical knowledge is ineffective to train students to be able to solve problems. In reality, Math teachers keep using conventional methods or techniques (Zulkardi, 2005) where teachers have a dominant role, whereas the students are passive. So far, the learning strategies being practised tend to be transferring knowledge to the students only. This strategy needs to be changed which encourages students to be creative in class to improve their learning achievement.

Human resources, in this case students who possess basic skills require teachers' ability to shift their teaching from traditional to become active and innovative so that the learning process runs according to educational development that suits the present needs. Innovative learning leads the students to become creative, independent and able to develop their thinking to overcome existing problems.

Besides choosing the strategies, teachers can also choose teaching methods or techniques that can attract students' interest in learning by grouping students into groups called cooperative learning. Cooperative learning is taken as experimental treatments in this study with the consideration that the teachers who have taught at SJSS in Pekanbaru generally still using conventional learning. The conventional learning is dominated by using expository method which the teachers are still dominated the learning. It means that learning is still centered on the teacher in the conventional learning while the cooperative learning is the student-centered learning.

Lie (2008) states that the cooperative learning gives the opportunity to the students to work together to do the assigned tasks where the role of the teacher is only as the facilitator. Slavin (2010) views that cooperative learning is a learning model that emphasizes social aspects in learning in which small heterogeneous groups of students are formed consisting of 4-6 students each. This type of learning strategy focuses on working groups in positive learning environment as opposed to individual competition and isolation within the academic environment. Slavin also stresses that students will understand difficult concepts when they discuss problems with their friends cooperatively. He also added that there are three main concepts that become the characteristics of cooperative learning; namely, mutual respect, individual responsibility, and the same chance to succeed. In addition, Ibrahim et al (2000) offer four characteristics of cooperative learning, (a) students work in groups cooperatively to deal with their learning materials, (2) students are divided according to their ability levels ranging from high, average, and low, (3) when possible group members come from different races, cultures, ethnic groups and sexes, (d) An appreciation or reward is given to groups rather than individuals. The application of cooperative learning in the teaching and learning process is in the stage of preparation, class presentation, group activities, evaluation, and group appreciation. The cooperative learning in this study went through the following stages:

\section{Preparation Stage}

In this stage the material to be presented is prepared, the individual score is identified, the students are put into cooperative groups and the teaching scheduled is made. The material to be presented is designed in such a way so that it suits the cooperative learning. Before the class starts, the task to be done by the cooperative groups is determined.

\subsection{Material Presentation}

The cooperative learning begins by presenting the material through an introduction, explaining the material and then guided exercises.

\subsubsection{Introduction}

The introduction covers what to be learned by the students in the group assignment and let them know about it. This information is intended to motivate the students and lead them to be curious about the concept to be learned.

\subsubsection{Explaining the learning material}

The material to be presented is matched with what to be learned by the groups. While this activity is in progress the teacher asks students questions and gives them feedback on their answers. 


\subsubsection{Guided exercise}

This form exercise is given by assigning the students to do the task or by asking them to find out the answers given in the task paper.

\subsection{Group Activities}

During group activities the teacher acts as the facilitator who monitors the groups' activities. The teacher distributed the task paper to each group as the material for the students to deal with. The teacher informs the students that the task paper is to be learned, not just to be completed and then handed them in to the teacher. In addition to learning the concept of the learning material, the task paper also served as a means for the students to exercise their cooperative learning skills. The students do the task individually or in pairs and after that shows each other what they have done to make sure they have done the right thing. If any members of the groups do not yet understand, the group members are responsible to explain before they ask the teacher's help.

\subsection{Evaluation}

The evaluation is made individually within specific time determined by the teacher. The scores obtained by the students are then processed to know the individual progress to be contributed to the groups.

\subsection{Group Values}

To determine the group values the following steps are used:

\subsubsection{Counting individual's and groups' scores:}

The counting of the individual test score is aimed to identify the progress being made to be contributed to the group. This individual progress score is counted based on the difference of the previous test score and the latest score. By so doing, every group has the opportunity to contribute the maximum score for the group. According to Slavin (2010) the criteria of the score contribution to the group can be seen in the table below:

Table 1. The Criteria of Score Contribution to the Groups

\begin{tabular}{|l|c|}
\hline Test Scores & Development Values \\
\hline More than 10 points below the basic score & 5 \\
\hline 10 points to 1 point below the basic score & 10 \\
\hline The same as the basic score to 10 points below the basic score & 20 \\
\hline More than 10 points above the basic score & 30 \\
\hline Perfect score (Not based on the basic score) & 30 \\
\hline
\end{tabular}

In this research the basic score means the basic score which became the standard of the grouping of the STAD type cooperative learning. So, the score which became the basic score in this research was the score obtained from the test of the previous topic.

\subsubsection{Giving appreciation of the group achievement}

The group score is counted on the basis of the average score of individual progress already gained. Slavin (2010) views that there are three appreciation levels given to the group, namely; (1) the group with the average score of 15 as the good group, (2) the group with the average score of 20 as the very good group, and (3) the group with the average score of 25 as the excellent group.

Slavin (ibid) argues that teachers or lecturers could change the above criteria if they wish. In this research, the researcher used the criteria that had been modified as follows: 
Table 2. The Criteria of Group Scores

\begin{tabular}{|c|l|}
\hline Average of Group Score Development & Criteria \\
\hline $5 \leq \bar{x} \leq 15$ & Good \\
\hline $15<\bar{x}<25$ & Very Good \\
\hline $25 \leq \bar{x} \leq 30$ & Excellent \\
\hline
\end{tabular}

There are several types of cooperative learning, among others, Student Team Achievement Division (STAD), Think-PairShare (TPS), and Number Head Together (NHT). According to Slavin (2010) The STAD cooperative learning has some important characteristics, i.e. group appreciation, responsibility and the chance to succeed. In addition, Slavin (ibid) states that STAD has more positive points, i.e. (1) students gain knowledge by developing that knowledge through interaction with other people, and (2) the learning evaluation system can increase students' motivation to perform better for themselves and for their friends so that collaboration can be built up among them.

On the other hand, according to Lie (2008) TPS cooperative learning gives a chance to students to work individually and collaboratively and improves their learning achievement. In addition, Spencer Kagan (in Ibrahim, et al, 2008) view that TPS has three steps in learning process:

1. Think: The teacher asks the students questions related to the learning material; then they are asked to think about the questions individually and then collaboratively.

2. Pair: The teacher asks the students to work in pair with their friends in the group of four to discuss the questions they have already thought in the thinking stage.

3. Square: The teacher asks the students in the group of four to discuss the questions raised by the teacher.

The THT cooperative learning is a learning model that uses a technique designed to influence the students' thinking patterns (Ibrahim et al, 2000). This type of cooperative learning gives students the opportunity to share ideas and consider the appropriate answers. Besides, this technique also encourages the students to be more responsible for doing the tasks, develop their collaboration and involve more students to discuss the learning material being presented and check their understanding about the content of the material (Lie, 2008).

The steps of the THT cooperative learning are as in the following:

1. Students are divided into groups and every student in the groups gets a number.

2. The teacher gives them a task and every group does the task.

3. The group determines the answers that are considered the best and ensure that every group member knows the answers.

4. The teacher mentions one of the numbers and the student whose number is being mentioned reports the results of their collaboration (Lie, 2008).

The learning activities of STAD are similar to the activities of the application of cooperative learning, whereas the activities of NHT and TPS cooperative learning are done by including the THT and TPS steps in the group activities in the cooperative learning.

The design of this study was the pre-test-post-test comparison group by Sukmadinata (2011). The treatment was conducted on three groups which were taken randomly. The three groups were given pre-test, and then each group was given the different treatment, namely cooperative learning model of NHT, TPS, and STAD. After that, the three groups were given the post-test. Meanwhile, the control group was the learning which were taught by conventional teaching before the given treatment to each class of experiments which the obtained data were the data of pretest. The diagram frame work of this study is as follows. 


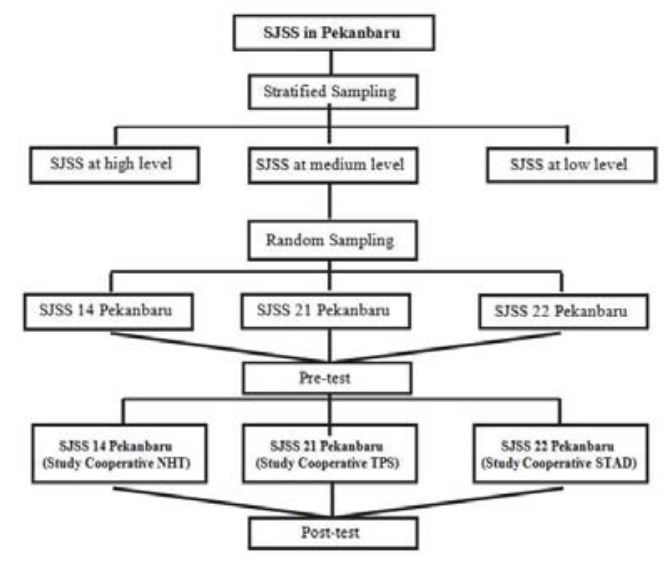

Diagram 1. The Framework of Study

\section{Formulation of the Problem}

The problem of the research is formulated in the following research questions:

1. Is there any difference between the students' learning achievement of Class VIII of State Junior Secondary School Pekanbaru in Math who are taught using STAD, TPS, and NHT cooperative learning in the academic year 2014/2015?

2. Is there any difference between the students' learning achievement of Class VIII of State Junior Secondary School Pekanbaru in Math before and after the treatment is given to every sample?

\section{Research Hypotheses}

1. There is a significant difference between the students' learning achievement of Class VIII of State Junior Secondary School Pekanbaru in Math who are taught using STAD, TPS, and NHT cooperative learning in the academic year 2014/2015.

2. There is a significant difference between the students' learning achievement of Class VIII of State Junior Secondary School Pekanbaru in Math before and after the treatment is given to every sample.

\section{Research Methodology}

This research was quasi-experiment with pre-test and post-test carried out towards three classes. According Sugiyono (2010) quasi-experimental research is a research method used to find out the effect of a certain treatment on others in a controlled condition. The design of this study was the pre-test-post-test comparison group by Sukmadinata (2011). The treatment was conducted on three groups which were taken randomly. The three groups were given pre-test, and then each group was given the different treatment, namely cooperative learning model of NHT, TPS, and STAD. After that, the three groups were given the post-test. Meanwhile, the control group was the learning which were taught by conventional teaching before the given treatment to each class of experiments which the obtained data were the data of pretest. Conventional learning is taught by teachers in each school with the same educational level, where they had completed education degree (S-1) and have been certified as educators. The research design can be seen in the following table:

Tabel 3: Research Design

\begin{tabular}{|l|c|c|c|}
\hline Class & Assessment (Pretes) & Treatment & Assessment (Postes) \\
\hline Experiment I & $\mathrm{O}_{1}$ & $\mathrm{X}_{1}$ & $\mathrm{O}_{2}$ \\
\hline Experiment II & $\mathrm{O}_{3}$ & $\mathrm{X}_{2}$ & $\mathrm{O}_{4}$ \\
\hline Experiment III & $\mathrm{O}_{5}$ & $\mathrm{X}_{3}$ & $\mathrm{O}_{6}$ \\
\hline
\end{tabular}


The design of pre-test-post-test comparison group by Sukmadinata (2011)

Descriptions:

O1: Pretest Scores of experiment Class I (Students of Class VIII SJSS 14)

$\mathrm{O}_{3}$ : Pretest Scores of Experiment Class II (Students of Class VIII SJSS 21)

$\mathrm{O}_{5}$ : Pretest Scores of Experiment Class III (Students of Class VIII SJSS 22)

$\mathrm{X}_{1}$ : Treatment of NHT Cooperative Learning

$\mathrm{X}_{2}$ : Treatment of TPS Cooperative Learning

$X_{3}$ : Treatment of STAD Cooperative Learning

$\mathrm{O}_{2}$ : Postest Scores of Experiment Class I (Students of Class VIII SJSS 14)

$\mathrm{O}_{4}$ : Postest Scores of Experiment Class II (Students of Class VIII SJSS 21)

$\mathrm{O}_{6}$ : Postest Scores of Experiment Class III (Students of Class VIII SJSS 22)

The beginning test instrument which is used to obtain the data of pretest is the instrument in the form of description which are arranged based on the subject before the treatment that has been validated by experts. While the instrument of post-test which is used to obtain the data of post-test is the description instruments which are organized based on the treatment subject and also had been validated by experts.

The used sampling is stratified random sample. The sampling was done by stratified SJSS in Pekanbaru to be three groups: SJSS at high level, medium and low. The school group that was taken was a school group at medium level consisting of 28 schools with consideration of students' abilities, the existing school infrastructure and teachers have the same ability relatively. Furthermore, The schools were randomly selected to be three schools and each school were randomly selected one class to be the research sample. The selected schools are SJSS 14, SJSS 21, and SJSS 22 which were given treatment cooperative learning model of NHT, TPS, and STAD.

The NHT, TPS and STAD cooperative learning types were performed by SJSS teachers where the research was taking place. First of all, the teachers were given a sort of training so that they knew how to apply the learning models. The samples of the research were the students of Class VIII of the odd semester SJSS 14 Pekanbaru totalling 32 students, and students of SJSS 21 as many as 34 students and the students of SJSS 22 with the total number of 34 students in the academic year 2014/2015. The samples were taken using simple random sampling technique while the data were collected using observation and an achievement test. The data obtained from observations were analysed using descriptive analysis, while the results of the achievement test were analysed using inferential statistical analysis. The data gained from students' achievement were analysed by employing one direction Anova test and t-test for paired observation data $a=0,05$ (Zulkarnain and Ritonga, 2007).

\section{Research Findings and Discussion}

The data obtained from observations indicated that there was improvement in the teaching and learning process compared to before the treatment was given whereby the students were taught using conventional methods in which the students used the formula given by the teachers without participating in finding the concept. Most students were already active in the teaching and learning process seriously and quietly because the teachers were able to manage the class and control if the students were ready for the lesson. The teachers were also able to manage time properly, the class atmosphere was already quiet, the students were studying seriously and were already prepared to present the material in front of the class. In other words, they were pleased to study collaboratively and being active in the groups to find the concept to be presented later. This means that the learning activities were better than before the new learning strategies were applied.

The analysis of students' learning achievement was carried out by analysing the results of the pre-test and posttest in order to test the hypotheses. One direction anova test was performed to test the hypothesis and the results were that (1) there was a significant difference between the learning achievement in Math of Class VIII SJSS Pekanbaru who were taught by using the NHT, TPS and STAD learning models in the academic year 2014/2015. The following are the results of the students' learning achievement in Math before and after the treatments were given to the group samples.

Table 4. The data of the students' learning achievement before and after the treatment

\begin{tabular}{|c|c|c|c|c|c|c|}
\hline & \multicolumn{2}{|c|}{ Exp I (Coop NHT) } & \multicolumn{2}{|c|}{ Exp II (Coop TPS) } & \multicolumn{2}{|c|}{ Exp III (Coop STAD) } \\
\hline & Before & After & Before & After & Before & After \\
\hline $\mathrm{n}$ & \multicolumn{2}{|c|}{32} & \multicolumn{2}{|c|}{34} & \multicolumn{2}{|c|}{34} \\
\hline$\overline{\bar{x}}$ & 73,38 & 85,34 & 70,06 & 80,32 & 70,41 & 82,97 \\
\hline $\mathrm{s}^{2}$ & 147,34 & 123,14 & 140,84 & 103,56 & 115,58 & 101.67 \\
\hline
\end{tabular}


The results of the data analysis of the pre-test using the one direction anova test show that the average score of Class VIII students' achievement of SJSS Pekanbaru is not significantly far different. It means that the three cooperative learning models provide similar effectiveness in the teaching and learning process. Furthermore, the data of the students' learning achievement were analysed through the results of the pre-test and post-test in order to test the hypotheses. It was found out that (2) there was a significant difference between Class VIII students' learning achievement in Math before and after the treatment was respectively given. The test used was the pair observation t-test. The data analysis shows that the average score of the students' learning in Math after the treatment is better than before the treatment, meaning that the three cooperative learning models given to the sample groups give positive effects to the students compared with the conventional learning strategies. The findings of the research support the study conducted by Zainab (2004). Dudley and Johnson (2003) argue that when students learn collaboratively, their learning outcomes will be better. The results of the students' class room assignments with the topic 'Relation and Function' resulted in the following results:

In indicator 1, the students were asked to give an example of relation in the daily life. The mistake made the students, for example, they did not give an example of relation in the daily life but showed the relation by way of a diagram by using a letter or a figure, and the answer given did not match the instruction. In indicator 2, the students were asked to give an example of relation in the form of an error diagram, Cartesian diagram and sets of regular pair. The mistake they made among others those who misplaced the sets at Cartesian diagram which they should have put the member of the first set (the name of student) was placed at the flat axis and the second set member (the test scores) were placed at the coordinate.

In indicator 3, the students were asked to give an example of function in the daily life. The made a mistake when answering, for example, they did not give an example of function in the daily life. They drew an error diagram by using a letter or a figure without an explanation. In indicator 4, there were three error diagrams and the students were asked to identify whether the error diagrams were the function. For the first error diagram, 2 students made a mistake because they thought that the first error diagram was the function; in fact, there was a member of the first set who did not have a pair at the second set. For the second error diagram, there was 1 student who did not give the answer while 9 students chose to answer the function without giving the reason, and 1 student made a mistake. The students thought that the second error diagram was not the function; they made a mistake in identifying the second error diagram. In the case of the third error diagram, they chose to answer the function without giving the reason and 1 student made a mistake. In fact, the third error diagram was the function, so they made a mistake in identifying the third error diagram.

In indicator 5, the students were asked to identify the domain, co-domain and the range of a function which was divided using the Cartesian diagram. It was found out that 1 student did not give the answer, whereas the mistake the students made in indicator 5 was that they made a mistake in identifying the co-domain and range while other students wrote domain as the range.

In indicator 6, the students were asked to count the number of mapping of two sets where both were a set of traffic lights colour and a set of vowel letters. The mistake made by the students, for instance, was that they only wrote the names of the traffic lights and vowel letters and wrote the names of their group members. There were also students who counted the number of mapping from one of the sets only so that the value was not perfect, whereas other students were not very careful in answering the item. The students got wrong in multiplying one of the numerals; the end result was that many mappings from one set were wrong.

In indicator 8, the students were asked to give an example of one by one correspondence in the daily life. The mistake made by the students when answering, for example, they did not give an example of one by one correspondence in the daily life. They drew an error diagram without including the names of the respective group members. There were also students who wrote the members of the set but did not give any explanation about name of one by one correspondence who contacted both sets. In indicator 8 , on the other hand, the students were asked to classify three presented functions in the form of chronological set pairs that were one by one correspondence. Their mistake, for instance, was that they moved the chronological set pair to the error diagram but did not give any explanation to their answers.

In the case indicator 9, the students were asked to identify the value of function. The mistake they made, for example, was that they failed to identify the results of the positive and negative numerals. In addition, some students only did half of the items given and then they just stopped. In indicator 10, on the other hand, the students were asked to identify the formula of a function, but they made a mistake, for example, they just followed some operational steps in doing the items and then they stopped.

Giving appreciations or rewards to outstanding students in the experimental groups either in every meeting or through daily exercises can motivate the students with lower achievement to better achievement to their groups. This matches a research finding which indicated that 'if students are given rewards because they do better than ever before, 
they will feel motivated to try to do things better.

(Gillies, 2003, Zaenab, 2004, Slavin, 2010; Zulkarnain, 2015).

\section{Conclusions and Suggestions}

\subsection{Conclusions}

Based on the findings of the research and the discussion, conclusions are drawn as follows: (1) there was no difference in learning achievement in Math of the students of Class VIII SJSS Pekanbaru who were taught using STAD, TPS, and NHT cooperative learning models in the academic year 2014/2015, (2) there was a difference in learning achievement in Math of the students of Class VIII SJSS Pekanbaru before and after the treatment was given to each sample. It showed that the given cooperative learning model to the three sample groups gave the better influence than the conventional learning.

\subsection{Suggestions}

With experience gained during the research, some suggestions are provided as in the following:

1. Cooperative learning models can be considered as one innovative learning alternative that can improve the students' learning achievement in Math.

2. Due to the limited time and fund, this research could only be conducted in a small scale; it is recommended that those interested in developing such a study can do it with longer time and a larger scope.

\section{References}

Armanto, Dian. (2002). Teaching Multiplication and Division Realistically in Indonesian Primary School: A Prototype of Local Instructional Theory. Disertasion. Enschede: Print Partners Ipskamp.

Direktorat Jenderal Pendidikan Dasar. (2006). Curriculum on Level Unit Education. Jakarta: Depdiknas.

Dinas Pendidikan Provinsi Riau.(2011). Data and Information of Education in Riau Province in 2010. Pekanbaru: Provincial Education Office of Riau Province.

Dudley, B. S \& Johnson, D. W. (1997). Using Cooperative Learning to Enhance the Academic and Social Experiences of Freshman Students Athletes. Journal of Social Psychology 137 (4). http://webl.epnet.com/eitation.asp.html. (4 November 2003)

Gillies, R. M. (2003). The Behaviors, Interactions, and perceptions of Junior High School Students During Small-Group Learning. Journal of Educational Psychology 95 (1), page 137-147.

Ibrahim Muslimin, etc. (2000). Cooperative Learning. Surabaya: University Press.

Lie, Anita., 2008, Cooperatif Learning, Jakarta: Grasindo.

Rohani, Ahmad. (2005). Learning Management. Revision Edition. Rineka Cipta: Jakarta.

Soedjadi, R. (2001). The Values in Maths Education and The Effort of Students Personal Development. Surabaya: Unesa

Slavin, R.E.,.(2010). Cooperatif Learning Teori, Research and Practice. Translate Lita. Jakarta: Nusa Media..

Sugiyono., (2010). Research Method of Education Approach Quantitative, Qualitative and R \& D, Bandung: Alfabeta,.

Sukmadinata, Nana Syaodih, (2011). Education Research Method. Bandung: PT.Remaja Rosdakarya.

Supartono. (2006). The development of Realistoc Math Lerning Set to Circle Subject at Class VIII SJSS 1 Bubulan Bojonegoro. Math edu; Vol 1 No. 2 Juli 2006.

Zaenab, Hanim. (2004). The Cooperative Learning Use on Math: The Investigation of Action in Low School in East Kalimantan, Indonesia. Thesis on doctor program fal. Bangi: Universiti kebangsaan Malaysia.

Zulkardi. (2005). The Improvement of Mathematics Education Quality through Learning. download at 11 Juli 2005 from http://www. pikiran-rakyat.com.

Zulkardi. (2007). The meaning of PISA, TIMSS, and Nasional Examination by Math Teacher. paper of national math education seminar . Palembang: PPS FKIP UNSRI, 4 September 2007.

Zulkarnain dan Ritonga, Zulfan. (2007). Education Statistics. Pekanbaru: FKIP Riau University.

Zulkarnain. (2011). Teaching and Math Learning through Contextual Problem: The Investigation of Action in Elementary School 004 Rumbai Pekanbaru. Tesis program doctor fal. Bangi:Universiti kebangsaan Malaysia.

Zulkarnain. (2015). The effect of STAD Cooperative Learning Initiated by Story Questions Toward the Ability to Complete Story Questions in Math of Class VIII Students at Junior Secondary School 1 and M.TSN in Pangean District, Kuantan Singingi Regency. Mediterranean Journal of Social Sciences 6 (3): page 102-109. 